\title{
Origem e significado do amor na mitologia greco-romana
}

\section{Love origin and meaning according to greco-roman mythology}

\author{
Ana Lúcia Nogueira BRAZ
}

\begin{abstract}
Resumo
O presente artigo visou compreender as possíveis origens e o significado do amor, utilizando como referência de análise a mitologia greco-romana. A escolha da abordagem mitológica justifica-se pelo fato de que, em nossa pesquisa, encontramos na cosmologia greco-romana uma das primeiras formulações e significado do amor através do mito de Eros e suas diversas repercussões. Utilizou-se dele para tornar mais claros os diferentes caminhos simbólicos concebidos para explicar a participação do amor no desenvolvimento e formação da psique individual e coletiva. Foram descritas e analisadas diferentes versões de Eros e suas possíveis influências na compreensão e vivência do amor nos tempos atuais. Em nossa análise, podemos afirmar, através do mito de Eros, que o amor é essencial para a realização e plenitude da pessoa, porque é o elemento que preenche de sentido a existência e humaniza as relações na medida em que abre espaço de existência para o outro junto a si.
\end{abstract}

Palavras-chave: amor; Eros; mitologia grego-romana; significado do amor.

\begin{abstract}
The proposal of the following paper was to identify all possible meanings of love through the Greek-Roman mythology. This mythology approach was chosen, as the Greek-Roman cosmology is one of the eldest love concepts and meanings through the Eros myth and its repercussions. This myth explores the symbolic possibilities to understand love influence on the individual and collective psiqué development. Many Eros versions have been analyzed in order to evaluate the actual love meaning possible influences. Considering Eros' myth, this paper concludes love is part of human being, as it can give human being's life and relationships meaning.
\end{abstract}

Key words: love; Eros; greek-roman mythology; love meaning.

O objetivo deste artigo é realizar uma análise inicial sobre as possíveis origens do conceito amor, seu significado e influência no contexto histórico, cultural e psicológico da civilização ocidental. Pelo fato de haver poucos trabalhos de pesquisas sobre o amor, esse é, em nossa concepção, um campo propício à pesquisa. Nesse sentido, uma investigação histórico-mitológica sobre a origem do amor poderá contribuir para desvendar um pouco mais o misterioso e interessante tema.
Num primeiro momento, procuramos analisar a etimologia da palavra e algumas definições de amor, com a finalidade de compreendê-lo de maneira ampla. Como fruto desta pesquisa inicial, encontramos na cosmologia (corpo de princípios míticos ou científicos que se ocupa em explicar a origem do universo) uma das primeiras formulações e significado do amor através do mito de Eros e suas diversas repercussões. Por essa razão, buscaremos rever as descrições do amor em diferentes vertentes mitológicas, buscando

\section{$\nabla \nabla \nabla \nabla$}

1 Instituto de Ciências Humanas, Curso de Psicologia, Universidade Paulista. Campus Chácara Santo Antônio, Rua Cancioneiro Popular, 210, 04710-000, São Paulo, SP, Brasil.E-mail: <aninhabraz@ig.com.br>. 
descrever o significado e o caminho do desenvolvimento amoroso, por essa ótica, com a finalidade de tornar o amor objeto de conhecimento mais profundo.

É importante lembrar que há grande influência dos mitos na história da humanidade. A psicologia, mais especificamente, utilizou-se deles para tornar claros os diferentes caminhos simbólicos concebidos para explicar o desenvolvimento do homem e a formação da psique individual e coletiva. Assim, Freud, Jung, Erich Fromm, entre outros muito contribuíram para que os mitos deixassem de ser vistos como simples lendas ou histórias e passassem a ser entendidos como soluções imaginativas elaboradas pelos povos a fim de solucionar os fenômenos inexplicáveis da natureza, os problemas de cunho emocional, pessoal e cognitivo que Ihes propõem sua existência. O mito também é definido como expressão simbólica dos sentimentos e atitudes inconscientes de um povo. Por essa razão, sua importância para a psicologia é tão grande.

Para Jung (1978), os mitos são fundamentais para se compreender a espécie humana, pois através deles é que acontecem as manifestações dos arquétipos, isto é, modelos advindos do inconsciente coletivo da humanidade que constituem a base de formação da psique humana. Os arquétipos têm como função revelar atitudes dos homens, dar uma significação ao mundo e à existência humana.

Dessa maneira, é possível compreender a universalidade dos símbolos, que, segundo Brandão (1988), se apresentam em todas as culturas e épocas de forma idêntica. Eles carregam consigo a possibilidade de vislumbrarmos nossa origem apenas por meio de seu significado, e, por sua vez, facilitam a recuperação da nossa memória e, portanto, da nossa consciência e identidade como ser humano. Nesse sentido, descrever algumas das várias versões do mito de Eros, que envolve o surgimento do amor, poderá contribuir para a compreensão do seu significado nos tempos atuais, assim como poderá resgatar uma parte da identidade da origem do ser humano.

Encontramos na mitologia greco-romana uma das primeiras formulações do significado do amor através das diferentes descrições do mito de Eros, o deus do amor. Embora a mitologia bramânica (indiana) também descreva a lenda de Kama, o deus do amor, a greco-romana foi escolhida por ter influenciado de forma mais direta a cultura ocidental em que vivemos.

Algumas narrativas que serão abordadas sobre a origem de Eros tiveram como base de referência autores clássicos como Hesíodo (1987) e Platão (2000), e copiladores como Brandão (1988) e Bulfinch (2000); esses dois últimos descreveram várias versões sobre o mito de Eros que auxiliarão na compreensão e análise da temática em questão.

\section{A origem do amor segundo a mitologia greco-romana}

De forma épica e poética, Hesíodo (1987), com a obra clássica "Teogonia", descreve como se deu a origem do universo e dos deuses segundo a mitologia greco-romana. A partir desse poema, também conhecido como novela, pode-se iniciar uma análise mais profunda da origem do amor.

\section{Versões sobre a origem do universo e de Eros}

O mito da origem do universo foi composto por Hesíodo, no século VIII a.C. Além de ser um épico, é, provavelmente, a mais antiga descrição de Eros que chegou até nós. Para o autor, o início de tudo se deu na era panteística (relativo a panteísmo: doutrina caracterizada por uma extrema aproximação ou identificação total entre Deus e o universo, concebidos como realidade única integrada). O universo se fez a partir do Caos (Káos), do vazio essencial, isto é, do espaço incomensurável de matéria eterna e rudimentar que pertencia à esfera do não ser; era uma massa confusa, na qual se confundiam os princípios de todos os seres. Do caos surgiram os deuses primordiais. A Terra - também denominada Gaia, Geia ou Vesta original, mãe universal de todos os seres, a sagrada mãe e origem de tudo - foi a primeira a surgir depois do caos. Das profundezas e entranhas da terra, nasceu Tártaro, um deus invisível que representa o inferno. Por fim, Eros, o deus do amor, desperta; ele é o responsável pela união amorosa entre todos os seres, aquele que possibilita a procriação de tudo que há no universo. É, também, o mais belo dos deuses.

Eros é a divindade primordial ou original responsável pela união amorosa entre os seres. Com 
isso, pode-se dizer que ele é preponderante para o surgimento da vida no universo, visto que apresenta grande influência sobre todas as coisas da natureza. A energia do amor é forte e avassaladora; para Hesíodo, não há ser que possa opor resistência a Eros, pois ele é a força cósmica da fecundação e multiplicação, e, conseqüentemente, perpetuação da vida, inspirando simpatia entre os seres para que se unam. Esse deus é também responsável pela união e ordenação das diferentes forças do universo ou da afinidade universal. Nenhum ser pode se furtar da sua influência ou força, seu poder vai além da natureza animada, ele une, mistura, multiplica não só humanos, mas várias espécies de vegetais, minerais, enfim, dá vida a toda a natureza; seus domínios envolvem todos e tudo. Dessa maneira, Hesíodo deixa bastante evidente a importância que atribuiu a Eros na formação do mundo. Como dito anteriormente, essa é, provavelmente, uma das primeiras explicações sobre a origem de Eros, porém, esse mito recebeu várias versões ao longo dos tempos que serão descritas sinteticamente a fim de podermos conhecer e ampliar nosso universo de análise sobre o amor.

Em uma das variantes do mito de Eros, encontra-se a Orfinica (filosofia originada na Grécia do século VII a.C., cuja origem é atribuída a Orfeu, que tinha a idéia de transmigração, de reencarnação da alma humana, após a morte corporal). Segundo ela, o deus nasce de um ovo primordial, concebido pela união de Caos (o vazio) e Nix (noite); das duas metades de sua casca surgem Urano (Céu) e Geia (Terra); do centro desse ovo nasce Eros, energia que garante a vida, força fundamental de união do mundo. É interessante notar que somente com o ovo primordial a vida na Terra torna-se viável. Nessa versão, Eros é visto como força de ligação e coesão do universo, trazendo em si o desejo de tudo ligar e unir.

Já na versão de Parmênides de Eléia, século VI a.C., o começo de tudo se deu a partir de dois princípios contraditórios: o Dia e a Noite, que separados nada podiam gerar. A formação de todas as coisas dependeria do equilíbrio recíproco entre esses dois elementos. Para tanto, nasceu Eros já com a responsabilidade de realizar a atração e o equilíbrio entre a própria contradição. E assim o faz, sendo, pois, considerado o fundador do Universo, bem como o da existência da vida nele.
Quase da mesma maneira acontece na genealogia de Empédocles, que data, segundo Durozoi e Roussel (1993), aproximadamente, de 420 a.C. É descrito o universo como sendo produzido por forças opostas, porém complementares. Philia, o amor, atua aproximando os diferentes seres e coisas da natureza, enquanto Neikos, o ódio, no sentido contrário, busca apenas união das coisas iguais. A ligação desses dois seres promoveu a constituição dos quatro elementos fundamentais: água, terra, fogo e ar. Através do poder de coesão do amor e do ódio, surgiram os diferentes elementos da natureza e os seres do universo.

Os deuses, isoladamente, nas diversas versões cosmogônicas descritas, criaram os espaços, o dia, a noite, a terra e o inferno, nos quais não se desenvolvia vida, que só surgiu por intermédio de Eros (gerador do processo de união), que promoveu, assim, seu desenvolvimento. Pode-se notar que Eros é considerado, nessas diversas genealogias citadas, um deus poderoso e fundamental. Por isso, alguns filósofos das Academias, segundo Brandão (1988), insurgiram-se contra a tendência generalizada de fortalecer a imagem dele. Desse modo, produziram-se novas cosmogonias, que atribuíram novas origens ao tão questionado deus.

No período de domínio romano, despontaram outras versões, passando Eros a ser visto como um deus de categoria inferior, um demônio (daimóin, palavra grega que significa deus de categoria inferior, intermediário entre os deuses e os mortais), que exercia seu poder sobre os homens. Por estar entre os humanos e as divindades, pois unia o "Todo" (os deuses) ao homem, era depreciado. Na mesma direção outra índole foi atribuída ao deus do amor. Na versão de Eurípides, Eros tem duplo caráter, num momento era força perniciosa que provocava a ruína dos homens e, em outro, o poder que levava a virtude e a salvação aos homens.

No período Alexandrino, o deus perdeu sua dimensão primordial para se tornar o promotor de aventuras perversas e galantes entre os mortais. Houve uma grande mudança na maneira de compreender sua origem e função. Nessa fase, ele perdeu suas características originais de deus primordial e passou a ser considerado como uma força ou uma energia que provocava um estado de insatisfação e inquietude no ser humano. 
Muitas versões diferentes continuaram a aparecer para compor a origem e desenvolvimento de Eros. Na mais conhecida ou popular na civilização ocidental, segundo Brandão (1988), Eros foi concebido por Hermes e Afrodite Urânia, a divindade dos amores etéreos. Filho da deusa do amor e da beleza, Eros foi descrito como companheiro e auxiliar constante de sua mãe, tendo como função realizar todos os seus desejos e pedidos. Dessa maneira, ele se tornou um ser sem vontade própria, usado como um objeto realizador das vinganças de Afrodite ou, simplesmente, mediador da sua diversão.

Em outra variante pouco encontrada, de autoria incerta, Eros é representado como um garotinho louro, alado e travesso. Conta-se que Afrodite, preocupada com seu filho que não crescia, queixou-se e pediu orientação a Têmis, deus profético da lei que, com sua sabedoria, esclareceu que o menino não crescia por ser uma criança muito solitária, por não partilhar nada e por não conhecer o sentimento de troca, nem de fraternidade. Têmis afirmou também que ele haveria de crescer se compartilhasse seu desenvolvimento e vida com alguém. Por fim, o deus da lei orienta Afrodite a ter mais um filho. Seguindo sua orientação, ela dá à luz Anteros, deus do amor mútuo e compartilhado. A partir desse nascimento, Eros passa a conviver com seu irmão, dividindo a atenção da mãe. Ao experimentar o sentimento de cuidado e amizade para com o outro, ele começou a se desenvolver e se tornar o deus mais belo e formoso do Olimpo.

De acordo com a história acima, Eros só foi capaz de se desenvolver quando experimentou vivenciar uma relação de troca, de atenção e cuidados, ou seja, um relacionamento próximo e afetivo com um igual. Anteros (anti-Eros), símbolo do amor recíproco, tem como característica ser um amor mútuo e infinito, que cresce quando compartilhado. Seu nome Ihe dá um caráter moderador, diferentemente de Eros que é perverso e essencialmente servo dos desejos e vontades de sua mãe. Anteros, por conseguinte, surge como oponente das maldades promovidas pelo irmão; $z \quad$ sua função era de enriquecer a si e ao outro por meio da entrega total, da generosidade e da reciprocidade. O amor que Anteros distribuía multiplicava-se sempre que era compartilhado com o outro, ou, em outras

66 palavras, quanto mais fosse dividido, maior se tornaria.
Com esse contato, Eros pôde se desenvolver e atingir a idade adulta. Por isso, o nascimento de Anteros prova que o crescimento e evolução são obtidos por intermédio do cuidado e amor gratuito. Amando Eros sem estabelecer condições, convivendo com suas maldades sem o julgar, estando próximo e disposto a ajudá-lo quando necessário, ele enriqueceu a si e ao irmão. Esse mito permite que se perceba a importância da reciprocidade nas relações de afetividade, nas quais o amor, para crescer, tem necessidade de ser compartilhado e multiplicado. Anteros, portanto, nasce com o objetivo de dar o sentido original ao amor fraternal, cuja característica básica é ser gratuito, mútuo e incondicional, isto é, independentemente do que é amado. Eros, ao perceber que era capaz de estabelecer uma relação amorosa, fraternal e incondicional, consegue se desenvolver e se tornar adulto, um ser único, inteiro e diferenciado.

Observa-se que essa versão é pouco conhecida e raras vezes encontrada nas diversas obras sobre o assunto. Vale salientar que é interessante e, até mesmo, estranho constatar que Anteros não é mais citado nessa e nem em outra genealogia. Não há continuidade de sua história. Nessa lenda, ele foi uma poderosa fonte de desenvolvimento e crescimento para Eros, mas logo desapareceu. Supomos que tal fato indique a desatenção e pouca importância dada aos sentimentos de fraternidade e de gratuidade ao longo da história dos homens ocidentais.

Diferentemente dessa, a alegoria que mais se tornou conhecida e preferida por poetas, escultores e pintores sobre a origem de Eros, segundo Brandão (1988), é aquela cujo deus é filho de Afrodite (deusa da vulgaridade e dos desejos incontroláveis) e Hermes (o intérprete da vontade dos deuses, patrono da ciência, aquele que conduz a luz para as trevas). Nessa narrativa, Eros é caracterizado como um garotinho alado, perverso, travesso e que jamais cresceu. De acordo com essa versão, o cupido se apresenta de olhos vendados, armado em uma das mãos com um arco e flecha, e segurando, na outra, um globo, que às vezes é substituído por uma tocha.

Tal simbologia de Eros pode ser compreendida quando se busca o sentido ou significado de cada ícone utilizado nessa representação. O primeiro símbolo é o da criança alada, muito travessa e perversa repre- 
sentando a juventude, imaturidade, irresponsabilidade e impulsividade. Essa imagem nos faz entender o quão infantil e adolescente é o amor, o que nos remete à idéia de que ele nunca chegará à idade da razão (logos), motivo de sua irracionalidade, sempre traquina e perversa, guiada somente pelo princípio do prazer.

O segundo símbolo é o arco e a fecha, uma arma de caça, indicando que o amor não é algo que venha sem esforço, pelo contrário, está ligado à luta para a conquista dos objetivos. É um instrumento de ataque e ao mesmo tempo de defesa, indicando que no amor há movimento constante, alternando tempos de tranqüilidade e de "guerra".

O terceiro símbolo é a venda nos olhos, significando a cegueira do amor. Eros se diverte, domina, apossa-se do outro mesmo sem vê-lo, talvez isso tenha dado origem ao tão conhecido e velho ditado popular:"o amor é cego". O deus em sua origem nunca vê quem é atingido pelas setas que despertam o amor.

O globo, representando o quarto símbolo, é traduzido como a universalidade do amor, que alcança toda a terra a ponto de ninguém poder escapar da sua força. A tocha, que, às vezes, substitui o globo, indica a força flamejante, quente e intensa do amor; é o fogo que arde constantemente no interior do ser humano.

Não é só nessa alegoria que Eros, companheiro inseparável de Afrodite e obediente de todas as suas ordens, é considerado o instrumento de vingança da deusa. Em razão da sua perversidade, deixa de ser a força unificadora, que se identificava em versões anteriores, converte-se em agente de divisão, pois está sempre servindo o princípio egoísta de Afrodite, passando a viver como um autômato, em estado de passividade.

Nas genealogias iniciais, século VII a.C., Eros é considerado o princípio gerador de vida e união, deus primordial que promove a junção das forças distintas do universo. Em detrimento disso, transforma-se, nas versões posteriores, em símbolo do egoísmo e perversidade humana como reflexo da influência de sua mãe.

Poucos são os mitos que sofreram uma transformação tão evidente e marcante ao longo da mitologia greco-romana. Talvez isso possa tanto indicar a dificuldade do homem em valorizar e dar um sentido amplo e desinteressado à existência do amor em sua vida, quanto traduzir as dificuldades do amor na vivência e consciência humana.

Por meio das narrativas citadas até agora, constatamos que Eros se transformou em mero servidor de sua mãe, cumprindo, digamos, um papel secundário nos mitos. No entanto, há uma versão em que o deus é protagonista e sua genealogia tem continuidade. Assim, em determinado momento, ao invés de impingir nos outros o amor, é irrompido por ele com uma de suas setas. Se antes o amor apenas pungia nas flechas lançadas contra os mais diferentes seres a fim de provocá-lo em cada um, agora, ao ser enfeitiçado por ele, sua vida se transforma: torna-se um ser inteiro e pleno. Essa versão, em que o deus do amor aparece mais adulto e com vida própria, é encontrada no clássico mito de Psique.

Tal lenda indica a dimensão do amor adulto e todas as dificuldades desse para se estabelecer e se manter. Devemos nos ater com mais detalhes à sua descrição por conter informações importantes, seja na questão da análise do amor maduro, seja por ser esse mito escolhido pela psicologia como símbolo de origem. Ao conhecer melhor a lenda, sua análise e compreensão poderão ser facilitadas.

\section{O mito de Eros e Psique}

Antes da analogia propriamente dita, é necessário esclarecer que "psique" é uma palavra derivada do verbo psýkhein, que significa soprar, respirar. Etimologicamente, "psique" significa sopro vital, vida, essência ou personificação do princípio da vida, princípio que anima o universo.

O mito de Eros e Psique é de origem grega e foi descrito por Lúcio Apuleiro (150 d.C.) no romance "Metamorfoses". O texto que segue é baseado nas obras de Brandão (1988) e Bulfinch (2000), encontrado no "Livro de Ouro da Mitologia"e em"Mitologia Grega, v.2".

Psique era uma linda princesa que tinha duas irmãs. Todas elas eram belíssimas e causadoras de muita admiração, assim, muitos vinham de longe apenas para vê-las. Psique, no entanto, era a mais nova e a mais bela. Com o passar do tempo, a linda ninfa começou a 
ser cultuada como própria encarnação de Afrodite, provocando, por isso, o esvaziamento dos templos da deusa. Cheia de ódio, Afrodite resolveu castigá-la, convocando seu filho Eros para mais uma missão: "Vês aquela audaciosa beleza? Vinga sua mãe das injúrias recebidas. Infunde no peito daquela donzela uma paixão por algum ser baixo, indigno de sorte, que ela possa colher a grande mortificação" (Bulfinch, 2000, p.101).

As duas irmãs mais velhas de Psique, não tão belas, já haviam se casado com príncipes. Psique, no entanto, sendo ainda mais encantadora, além de extremamente graciosa, não conseguia um marido para si, pois todos temiam tamanha beleza. Vivia, portanto, em seus aposentos, amargando uma deplorável solidão. Seus pais, desorientados, foram buscar ajuda do oráculo de Apolo. Ao questionarem sobre o futuro da filha, receberam como resposta que Psique não foi destinada a ser esposa de um mortal, e, segundo ele, seu marido a esperava no alto da montanha. Assim, foram instruídos pelo oráculo a vestirem-na com roupas próprias de casamento e a deixá-la no alto de um rochedo onde um monstro horrível iria buscá-la.

O rei e a rainha se encheram de desânimo e entraram em desespero. Indagavam, entre eles, o triste fim para a tão bela e jovial filha. Psique, corajosa e certa de seu destino, disse a eles: "Por que lamentais, queridos pais, resigno-me ao meu fim, levai-me àquele rochedo a que me destinou meu desventurado destino" (Bulfinch, 2000, p.101). Obedecendo à profecia do oráculo, seus pais deixaram-na no alto de uma montanha. Tremendo de medo e sozinha no topo, a moça logo adormeceu.

Tudo estava de acordo com o que Afrodite havia planejado. Eros se aproximou para completar mais uma de suas missões. Não obstante, ao se deparar com tamanha beleza e formosura da mortal, ficou perturbado e feriu-se com sua própria seta, apaixonando-se $\gg \quad$ no mesmo instante. Encantado, Eros mandou que Zéfiro (vento) conduzisse a bela que estava adormecida até seu palácio. Ao despertar, Psique se viu num maravilhoso castelo de ouro e mármore. Maravilhada com o lugar, percebeu que ali tudo era mágico. As portas se abriam para ela, vozes sussurravam a respeito de tudo o que precisava saber. Servos invisíveis cercavam-na e tudo faziam para agradá-la.

Já era noite quando a bela voltou aos seus aposentos, deitou-se e, na mais total escuridão, percebeu, ao seu lado, a presença de alguém. Pensou ela que só poderia ser o seu esposo predestinado pelo oráculo. Naquela noite, Eros desposou-a com muita delicadeza e profundo amor. Advertiu-a de que seria o melhor dos maridos, mas que ela jamais poderia vê-lo, pois isso significaria perdê-lo para sempre. Psique, encantada pela noite de amor, concordou de imediato. Assim foram seus dias. A moça tinha tudo que desejava. Seu marido Ihe dava a sensação do mais profundo amor e era extremamente carinhoso. Psique a cada dia o amava mais.

Com o passar do tempo, porém, ela começou a sentir saudade de seus pais e pediu permissão ao marido para visitá-los. O deus, através de sua onisciência, advertiu de que essa viagem traria péssimas conseqüências. No entanto, Psique suplicou-lhe permissão, argumentando não ter ninguém para falar ou ver durante o dia. Apaixonado, Eros não resistiu às súplicas e, mesmo correndo o risco de perdê-la, concedeu-lhe a graça de ver sua família. Zéfiros, da mesma forma que a havia conduzido ao palácio, levou-a ao reino de seus pais.

Psique, recebida com muita alegria, distribuiu muitos presentes a todos. Suas irmãs, ao verem-na tão bem, encheram-se de inveja e começaram a crivá-la de perguntas acerca do marido. Psique, inocentemente, contou-Ihes que nunca tinha visto sua fisionomia. Essa resposta foi suficiente para que suas irmãs enchessem-na de medo, relembrando a história do oráculo que dizia ser seu marido um horrendo mostro. Por fim, convenceram-na de desmascará-lo ao contar que os camponeses e caçadores da região viam todas as noites, atravessando o rio vizinho em direção ao palácio, um monstro que, certamente, era o marido de Psique, e que apenas aguardava o momento oportuno para devorá-la, bem como a criança que esperava em seu ventre. Por essa razão, aconselharam-na que depois do pôr-do-sol ela deveria iluminar, cuidadosamente, o rosto da terrível criatura e, com um só golpe, cortar-lhe a cabeça antes que fosse devorada.

Evidentemente que a intenção de suas irmãs era apenas prejudicar Psique, já que ela havia feito a 
promessa a seu esposo e, se a mesma fosse quebrada, conseqüentemente, seu casamento também seria. No retorno para casa, transtornada, apavorada e sozinha, a curiosidade e o medo tomaram conta do coração humano da donzela; as histórias contadas por suas irmãs surtiram efeito.

Tão logo veio a noite, tomada pelas influências das duas princesas, Psique esperou que Eros adormecesse para acender uma vela e assim poder vê-lo. Surpreendentemente, ao se deparar com tão linda figura, perdeu-se em sonhos e ficou parada embevecida, admirando-o. Foi nesse instante que um pingo de cera fervente caiu sobre o peito de seu marido antes oculto, despertando-o bruscamente em razão da dor e da queimadura, que produziu uma grande ferida.

Decepcionado e magoado com a quebra da promessa da esposa, partiu, fazendo cumprir sua promessa de outrora. Abandonada por Eros, sentindo a dor da perda do amor que havia desperdiçado, ficou profundamente infeliz. Psique, desesperada, atirou-se nas águas de um rio, que a devolveu ao solo. Então, passou a caminhar dia e noite sem repouso nem alimento, à procura do marido.

Aconselhada por Pã (deus dos rebanhos e dos pastores) a enfrentar as dificuldades de maneira produtiva, a princesa decidiu recuperar seu amado, tentando ultrapassar o ódio de Afrodite. Dirigiu-se à presença da deusa e, de forma humilde, modesta e submissa, pediu seu perdão. Afrodite, depois de torturá-la e insultá-la, infligiu a ela quatro missões, consideradas humanamente impossíveis. Psique, depois de suportar todas as torturas, aceitou as provas propostas com intuito de recuperar a vida e o amor de Eros.

Sua primeira prova foi separar por espécies, em uma única noite, milhares de grãos misturados em um enorme monte. A bela moça, diante de tão difícil tarefa, pôs-se a chorar de desespero e agonia, já que não haveria tempo suficiente para realizar tal missão. A solução foram as formigas que, vendo seu desespero, resolveram ajudá-la. Trabalhando incansavelmente, haviam cumprido a tarefa já ao anoitecer, sem maiores dificuldades.

A segunda prova que teria de realizar era trazer flocos de lã, polvilhados de ouro, pertencentes a ovelhas selvagens, agressivas e carnívoras. Disposta a fazer o que estivesse ao seu alcance, a bela foi à margem do rio a fim de jogar-se nele e alcançar a outra margem. Porém, o rio deus inspirou os juncos e plantas ribeirinhas a murmurarem súplicas para que ela não desafiasse a correnteza do rio e não enfrentasse os temíveis carneiros venenosos, enquanto o sol estivesse a pino. Aconselharam-na, então, a voltar ao anoitecer, pois o rebanho estaria recolhido e o espírito sereno do rio já estaria presente, assim poderia atravessá-lo com tranqüilidade e poderia pegar os muitos flocos de lã que permaneceriam presos à vegetação e, desse modo, ela poderia completar sua prova com segurança. E assim o fez. Logo depois, voltou à presença de Afrodite com o avental repleto de lã de ouro.

Afrodite, repleta de fúria com o sucesso de sua "nora", ordenou, como terceira prova, que buscasse as águas sagradas e escuras dos rios infernais. Ao mesmo tempo em que eram as mais perigosas da região, as águas alimentavam o rio infernal, guardado por dois dragões. Psique deveria encher um recipiente de cristal, depois de enfrentar os terríveis guardiões da fonte. Dessa forma, a esposa de Eros foi em direção à fonte, escalou com muito custo a montanha e viu então os dois enormes dragões rastejando sobre as pedras a cuidar da fonte. Essas criaturas jamais deixavam de vigiar as águas sagradas.

Diante da impossibilidade da realização da prova, ficou petrificada e com medo. Pensou em se matar. No entanto, Zeus, comovido, lembrou-se da grande ajuda de Eros há tempos e resolveu ajudá-la. Enviou-lhe sua águia que, tomando a jarra pelo bico, num vôo rápido, passou entre os dragões, encheu o recipiente de água e o devolveu a Psique. Ela, cheia de esperanças, voltou humildemente ao encontro de Afrodite para lhe entregar o jarro com água.

Finalmente, sua última prova, a mais difícil, era ir até Perséfone, no reinado de Hades, deus das profundezas do inferno, e pedir um pouco de juventude e beleza eterna, em nome da mãe de Eros. Psique, certa de seu fim, já que a única maneira de chegar às profundezas do inferno era por meio da morte, subiu ao alto de uma torre com o propósito de se atirar. A Torre, porém, falou com mansidão à Psique para que não recuasse ante a prova derradeira. Deu-lhe ânimo e instruiu-a acerca do caminho mais curto para atingir o mundo dos mortos, explicando-lhe, ao mesmo tempo, 
as precauções que deveria tomar na longa caminhada pelas trevas. Depois de ouvir com atenção as advertências da Torre, a moça foi adiante e entrou numa cavidade do chão, onde se encontrava a planície do palácio de Hades. Psique não podia ir de mãos vazias devido aos obstáculos que encontraria ao longo do percurso, por isso, levou na boca dois óbolos (moedas gregas) e em cada mão um bolo de cevada e mel. Além disso, teria de tomar muito cuidado, pois encontraria pelo caminho algumas tentações.

A primeira delas foi no meio do caminho. Era um homem que the pediu ajuda para apanhar alguns gravetos, lembrou-se, porém, da admoestação da Torre; não lhe deu ouvidos e seguiu seu caminho. Ao chegar no rio dos mortos, encontrou o barqueiro Caronte, a quem entregou as moedas que garantiriam sua passagem de ida e volta. No meio da travessia, Psique defrontou-se com a segunda tentação: um velho que Ihe havia implorado ajuda para subir no barco. Entretanto, conforme as recomendações da Torre, não se deixou vencer pelo sentimento de piedade ilícita. Terminada a viagem de barco, avistou, à sua frente, o castelo, cujo guardião era um cão de três cabeças, o Cérbero. De acordo com as determinações da Torre, deu a ele um dos bolos para poder entrar e o outro guardou para a saída.

No interior do castelo, encontrou a terceira tentação; algumas velhas tecedeiras solicitaram sua ajuda, no entanto, não Ihes deu atenção. Já no salão do palácio, a moça se deparou com Perséfone, que lhe ofereceu uma deslumbrante cadeira para descansar e iguarias apetitosas para saciar sua fome. A princesa recusou tudo, pois sabia que era mais uma das seduções. Por isso, sentou-se no solo e pediu apenas um pedaço de pão preto, e expôs a razão de sua visita. Depois de receber o pacote, voltou pelo mesmo caminho, passando, novamente, por todas as tentações, lembrando-se que dependeria somente dela curar e reencontrar Eros, seu grande amor.

Ao sair vitoriosa do mundo das trevas, uma $? \quad$ grande curiosidade lhe assaltou o espírito. Para isso ela u não havia se preparado, isto é, não esperava pela última, inesperada e pior das tentações. A Torre, sabiamente, aconselhou que não abrisse a caixa, em hipótese alguma. No entanto, sem conseguir dominar sua

70 curiosidade humana, desejava saber qual era o segredo da juventude eterna. Sem esperar, abriu a caixa de Perséfone e caiu em sono profundo.

Eros, já quase recuperado de seu ferimento, foi encontrar sua amada, pois estava cansado de vê-la sofrer e passar por tantas provações. Chegando lá, após retirá-la do sono da morte, explicou como sua curiosidade poderia tê-la levado ao fim. Mesmo assim, o deus pediu que concluísse sua tarefa. Psique levantou-se e, cuidadosamente, levou a caixa para Afrodite, completando, com isso, todas as provas ordenadas por ela.

Finalmente, Eros implorou a Zeus, o deus dos deuses, que tivesse compaixão dos dois e do amor entre eles, e solicitou uma permissão especial para que pudessem se unir, pois até então os deuses do Olimpo nunca puderam se casar com mortais. Benevolente, Zeus advogou com muito empenho a favor dos enamorados e conseguiu consentimento dos outros deuses, até mesmo de Afrodite, para a união do casal. Psique foi chamada ao Olimpo para a assembléia celestial. Lá recebeu a benção de Zeus que também Ihe concedeu a imortalidade.

Eros e Psique permaneceram juntos por toda a eternidade. Tiveram apenas uma filha, Prazer. Na linguagem dos mortais, chama-se Volúpia, que significa prazer dos sentidos e das sensações.

\section{Compreensão do mito}

Após a leitura de um mito interessante e belo como esse, percebemos novamente a importância do amor no processo de desenvolvimento da vida e do amor adulto. Psique representa o princípio da vida, da alma humana purificada por sofrimentos e infortúnios provocados por desconfiança e curiosidade, atitudes típicas dos mortais. Depois de passar por todos esses sofrimentos, Psique torna-se preparada para gozar a pura e verdadeira felicidade.

Analisando o desenrolar da lenda, pode-se deduzir que o amor não aceita desconfianças nem mentiras. No momento em que a confiança de Psique foi questionada por suas irmãs, quando duvidou da pureza e incondicionalidade do amor de Eros, a bela deixou-se levar por esse sentimento. A relação, até então forte, rompeu-se. Eros, ferido fisicamente e agredido em seu sentimento mais profundo, puro e 
primitivo, não conseguiu reagir. Fisicamente, sua ferida não fechou e a dor interior só conseguiu ser superada quando houve uma prova: a luta desesperada de Psique por ele e por seu amor. Ela teve de enfrentar todos os seus medos, fraquezas e, sobretudo, o ódio de Afrodite para, só assim, Eros perceber que ela o amava e não duvidava mais dele. Psique, apesar de tudo, apresentou-se como uma mulher decidida e disposta a conquistar novamente o amor perdido, bem como a confiança de seu amado. Mostrando-se arrependida, resolveu, humildemente, enfrentar todas as maldades, torturas e desafios impostos por Afrodite.

A partir dessa situação, conclui-se que a lenda sugere aos leitores que por amor tudo deve ser enfrentado, mesmo quando se colocam à prova todos os medos e fraquezas. Além disso, o mito procura insinuar todas as possibilidades e condições pessoais, mentais e espirituais para se viver de forma integral e com seu verdadeiro amor, experimentando a felicidade e a alegria do encontro profundo.

O amor de Psique, assim como qualquer amor verdadeiro, a fez superar suas fragilidades humanas, proporcionando seu crescimento e amadurecimento. Em outras palavras, ao terminar sua longa jornada de desafios, ela saiu da condição de simples humana sendo elevada à imortalidade (deusa). Esse é o mais verdadeiro e profundo sentido do amor, pois ele nos faz ultrapassar milhões de barreiras para atingi-lo e tornar-se eterno.

Brandão (1988) consegue expressar, sintética e poeticamente, a importância desse mito para a compreensão mais aprofundada do arquétipo e mistério do amor ao dizer que "a mulher humana, como indivíduo, escalou o Céu e a partir daí, na perfeição conquistada pelo mistério do amor, a mulher encontrou-se lado a lado com os arquétipos da humanidade inteira, os Deuses imortais" (Brandão,1988, p.250).

Com essa conquista, o amor (Eros) foi capaz de perdoar todas as fraquezas, inseguranças e imaturidades do outro (Psique), conseqüentemente atingiu sua maturidade. Partindo dessa idéia, Eros, um jovem aventureiro, perverso e traquina, torna-se adulto e responsável ao desobedecer sua mãe, desposando Psique, a grande rival de Afrodite. Nesse momento percebeu ter vontade própria, pois notou a existência de um outro ser. Vivo e desejoso de amor, uniu-se a uma mortal que, mesmo repleta de falhas (ingenuidade, inveja, ciúme, curiosidade, vaidade, dentre outras), é aceita e perdoada, pois quando o amor é verdadeiro não se impõem condições para vivenciá-lo.

Essa simbologia permite que se faça uma reflexão sobre a importância do amor na construção da pessoa humana, pois foi preciso que Eros, um semideus, sem vontade e sem autonomia própria, para que pudesse ser alguém com vontades próprias, fosse tocado por outra pessoa (sopro da vida Psique) que, através de sua simplicidade e humanidade, descobriu em seu interior força e coragem para superar seus medos, dificuldades e fragilidades em busca do alívio de sua dor e de seu amado, assim encontrando a felicidade e completude.

Da mesma forma que a lenda, o conceito de amor sofreu transformações ao longo do tempo, adequando-se às necessidades sociais, culturais e ideológicas dos diversos povos.

Com o intuito de conhecer mais definições míticas do amor vigentes em diferentes épocas da nossa história cultural ocidental, sintetizamos algumas idéias de influentes pensadores, que, certamente, em muito contribuíram para desvendar um pouco mais esse misterioso fenômeno.

\section{Outras versões mitológicas de eros}

Iniciaremos com Platão, que viveu de 428 a 347 a.C. e foi um dos mais importantes filósofos a se preocupar com a presente temática, dedicando uma obra inteira à importância e ao significado do amor.

Em 385 a.C. compôs "O Banquete" - considerado sua mais brilhante criação e um dos textos chaves da cultura clássica ocidental -, uma das primeiras tentativas de análise e compreensão do amor ao iniciar a busca para a sua revelação.

O objetivo desta parte é realizar uma pequena síntese dos diálogos e elogios que alguns filósofos teceram a Eros, a fim de compreender as interferências da referida obra no pensamento moderno ocidental.

Aristófanes inicia seu elogio dizendo: "Ele é, de todos os deuses, o mais filantropo, o protetor dos humanos e médico de males que, se fossem curados, resultaria daí a mais perfeita felicidade para a raça dos 
homens" (Platão, 2000, p.67). Esse filósofo descreve o amor como sendo o responsável pela união das duas metades separadas desde a origem do ser humano. Aristófanes, para fazer seu elogio a Eros, discorre, inicialmente, sobre a origem da natureza humana e suas paixões. De acordo com ele, no princípio do mundo existiam três gêneros: masculino (filho do Sol), feminino (filho da Terra) e andrógino (filho da Lua), que reunia, num único ser, o princípio masculino e feminino.

Esses seres especiais tinham forma esférica, deslocavam-se circularmente ou de maneira ereta, possuíam quatro mãos, quatro pernas, duas faces absolutamente idênticas, porém um único cérebro. Além dessa peculiar aparência, eram donos de uma força terrível e vigor fora do comum, por isso, resolveram, um dia, subir ao Céu para atacar os deuses e tomar o Olimpo. Chegando lá, não conseguiram realizar seus desejos e foram dominados pelos deuses.

Zeus e os outros resolveram dar um grande castigo a seres tão soberbos. Cortaram-nos ao meio, deixando-os mais fracos, numerosos e submissos, dessa forma podiam servir aos deuses e à própria espécie humana. Feita a divisão, coube ao deus Apolo acertar a parte estética. Puxou a abertura dos lados para frente, e apertou um cordão ao redor da única abertura que havia restado, deixando uma marca em seu ventre, o umbigo, que serviria para lembrar o quanto sofreram em sua origem.

Cada metade sentia-se fraca e incapaz, desejando apenas reencontrar a outra. Isolada, com o tempo ia perdendo suas forças de tanto almejar a parte perdida, pois nada fazia quando sozinha. Quando as duas metades se encontravam, agarravam-se e não mais se largavam por medo de se perderem novamente. Dessa maneira, muitas morriam de fome e de inatividade, pois além de não fazerem nada quando separadas, unidas também não conseguiam realizar nenhuma tarefa. Se uma das metades morria, a segunda, abandonada, procurava a quem se agarrar novamente, fosse um homem ou mulher. Continuando isso a ocorrer, a conseqüência seria a extinção da $\underset{m}{*}$ espécie humana, pois não importava a quem iria se ligar, nem o sexo dessa pessoa, queria apenas sentir-se unida, precisava de alguém para completá-la, não era capaz de fazer nada além de ficar agarrada. Essa“união" improdutiva impediria a propagação da raça humana.
"Compadecido, Zeus imaginou um meio: desloca os seus sexos e os põe para frente, até aí tinham-no atrás, procriando-se e reproduzindo-se não uns graças aos outros, mas à terra, como fazem as cigarras" (Platão, 2000, p.70). Com a mudança, poderiam se reproduzir por meio da união fecunda entre a parte masculina e a feminina.

Desde então, o amor mútuo passou a ser inato à espécie humana, que, segundo Aristófanes, procura reconstruir sua unidade a partir da metade perdida. Por intermédio da combinação e união mútua (fecundação), curam sua natureza ferida e se "fundem em um só". Enquanto estiverem unidos como um único ser, ou seja, vivendo uma vida comum, encontram sua natureza primitiva e reconstroem sua totalidade, gerando o sentimento denominado amor.

Nessa alegoria, nota-se que o amor serve de catalisador entre "seres separados". Desde o momento da divisão do andrógino, todos os seres humanos carregavam a sensação de solidão e incompletude. Por essa razão, pode-se entender como uma das metas da vida é a união com o outro na tentativa de encontrar o sentido de plenitude e unidade.

Para Aristófanes, os humanos apenas se sentirão completos quando encontrarem sua outra metade perdida e tal união só pode ocorrer por intermédio da força do amor. Esse mito pode explicar a origem, em muitas pessoas, da procura insaciável por uma companhia que the recomponha a unidade, que lhes ajude a enfrentar os desafios da vida, dando origem ao sentimento de amor que as pessoas têm umas pelas outras. Nesses termos, o amor possibilita o encontro do ser humano com sua natureza e unidade original, levando-o à felicidade, à paz e à alegria interior.

Ao longo dos séculos, acreditou-se que o amor, através da fusão de duas almas e dois corpos, tornaria o homem pleno. Essa maneira de compreender a origem da espécie humana vem exercendo grande influência no pensamento ocidental no que diz respeito à escolha amorosa, considerada por muitos o ato mais importante da vida.

Outro elogio contido na obra "O Banquete" é de Fedro, que caracteriza o deus do amor como força vital e imortal da humanidade, visto "que Eros é, entre os deuses, o mais antigo, o mais carregado de glória, e Senhor soberano de proporcionar a virtude e a 
felicidade aos homens nesta vida e depois da morte" (Platão, 2000, p.50). Segundo Fedro, Eros é primordial e o responsável pela vida no universo, ele promoveu a união do universo e é, portanto, a semente de toda a vida em sociedade. De acordo com Fedro, a função de Eros é de intermediário, porque está entre o Olimpo e a Terra. Ele elucida o que vem do Céu à Terra e viceversa. Isso é o que o torna capaz de preencher o vazio existente entre os homens e os deuses. Fedro coloca Eros como responsável pela existência do amor divino e também como aquele que não apenas liga as almas humanas aos deuses, mas é encarregado pela união de todos os animais, plantas e objetos.

Essa explicação sobre a origem de Eros nos ajuda a entender a razão de muitas pessoas definirem o amor, por um lado, como um sentimento superior e divino, que está acima das vontades humanas, que eleva o ser amado e o amante a uma sensação de imortalidade e onipotência, e, por outro lado, como um sentimento que em sua ausência promove uma sensação de incapacidade, inferioridade e conseqüentemente de depreciação e infelicidade.

Ainda na obra "O Banquete", durante o elogio atribuído a Sócrates, menciona-se que a sacerdotisa Diotima define Eros como um deus inferior pelo fato de estar entre o Céu e a Terra. Diotima inicia seu diálogo descrevendo a origem de Eros: tudo começou em uma festa no Olimpo, quando os imortais reunidos festejavam o nascimento de Afrodite, a bela deusa do amor. Todos estavam alegres e bebendo o néctar que estimulava a expansão da despreocupação e alegria. Terminada a festa, Penia (deusa da pobreza) entrou no salão com o objetivo de pedir os restos do banquete. Antes de fazer o pedido, porém, vislumbrou a figura de Poros (deus dos grandes meios ou também deus da riqueza) que, embriagado pelo excesso de néctar, afastou-se dos imortais, entrou no jardim de Zeus e despencou de sono. Penia, que vivia sempre à procura de coisas materiais, de recursos para sobreviver, resolveu, naquele instante, ter um filho de Poros. Para isso, dirigiu-se ao jardim e, sem ruído, deitou-se junto a ele. Ao abraçá-lo, Poros despertou. Penia, então, o convidou a desfrutar de sua companhia e de seu corpo, e o deus aceitou. A deusa, assim, atingiu seu objetivo. Poros, sem muita consciência, engravidou Penia, que concebeu o filho desejado: Eros (amor), gerado no dia do nascimento de Afrodite, sendo para sempre seu servo e companheiro.

Eros sempre foi ambíguo, pois herdou do pai (grandes meios ou riqueza) a coragem, decisão e energia, tornando-se um astuto caçador, ávido do que é belo e prazeroso. Por outro lado, herdou de sua mãe (pobreza) a carência permanente e o destino de andarilho. Não é mortal nem imortal, ora germina ora vive, uma vez que morre, outra de novo renasce. Marcado por uma carência constante, herdada de sua mãe, não é sábio, mas se esforça sempre para conhecer e ir mais além, aventurar-se em busca de novos conhecimentos, pois ama a sabedoria e a filosofia que herdou do pai, Poros.

Essa alegoria, segundo Brandão (1988), é uma das primeiras genealogias que se manifestou contra aquela tendência generalizada que classificava Eros como um dos mais importantes deuses mitológicos de uma época. Nota-se que pelo fato de passar por toda a arte sagrada das imolações e purificações, é um ser perdido, que não tem seu espaço no Olimpo nem na Terra, está sempre à procura de seu lugar e nunca o encontra.

O amor, dessa forma, é duplo e maniqueísta em sua origem. Orientado pela beleza e filosofia (ou estética e inteligência/razão), qualidades herdadas do pai, e pela mortalidade, ausência de meios materiais e mentais, e pelas carências advindas da mãe, Eros foi concebido pelo princípio da falta. Se analisarmos a origem do amor utilizando essa alegoria, seria possível explicar as insatisfações constantes de muitos daqueles afetados por ele. Muitos amantes são insaciáveis, querem sempre mais de seus parceiros, cobram de seus pares mais atenção, mais dedicação, mais afeto, suas exigências são intermináveis mesmo quando repletos de amor. Isso por que o amor, talvez, em seu princípio, seja orientado pela carência, falta constante e também pelo desejo de ir além dos recursos que tem.

Já foi ressaltado, de alguma forma, neste presente trabalho, que o desejo se manifesta primeiro por um corpo belo (estética), depois por belas atividades e ocupações (lógica e filosofia). Porém, o homem nunca se satisfaz, parece que não sabe exatamente o que quer e qual seu lugar. Assim, o amor é elevado a um plano ideal, que transcende o físico ou material, sem, porém, excluí-los. Por estar entre o Céu e 
a Terra tem algo de divino e mítico e, por outro lado, tem seu perfil terreno, mortal e finito. Assim Eros deixa de ser, segundo Brandão (1988), um deus poderoso, como em outras genealogias, passando a ser uma energia eternamente insatisfeita numa busca inquietante de algo que não existe, pois tem a carência nascida de sua origem e, em contrapartida, vontade de tentar sempre alcançar uma plenitude que nunca conquistará.

Com essa alegoria, Platão aponta como responsabilidade do ser humano dar ascensão intelectual e espiritual à força de Eros. Nesse sentido, a elevação do amor é uma questão de inteligência e, portanto, essencialmente masculina, lado herdado de Poros. O intelecto, nessa versão platônica, é considerado também um elemento importante e fundamental para a compreensão e vivência do amor. Emoção e razão passam a fazer parte do mesmo fenômeno, o equilíbrio entre esses dois aspectos é o ponto de maior importância para o desenvolvimento do processo amoroso.

Essas várias percepções de Platão, presentes na obra "O Banquete", influenciaram a compreensão da origem e significado do amor naquela época e acredita-se ainda continuar interferindo nas diferentes maneiras de se compreender suas muitas características.

\section{Discussão e reflexões sobre o mito de Eros}

A presente discussão consiste na reflexão sobre as principais características do mito de Eros e sua repercussão na vivência e compreensão do amor. Quanto à sua procedência, podemos dizer que o amor está na base, na origem da vida na terra e do ser humano. Segundo a cosmogonia, Eros é o responsável pela união de tudo que existe, portanto, sem ele a vida na terra seria impossível. Também podemos destacar a importância do amor na fase inicial da vida, e os riscos de desorganização interna e imaturidade quando ele não está presente. Noções presentes na versão de Eros e Anteros.

O amor também é visto como uma vivência que proporciona um encontro verdadeiro com o Eu supremo e divino, que compõe o sentido da existência e fortalece a sensação de pertencer a algo maior, dando um significado à existência. Esse amor único é também desligado do tempo, por isso é considerado atemporal e imperecível, algo que não passa, pois tem sua porção divina, como descrito por Fedro.

Segundo Aristófanes, podemos compreender melhor o desejo freqüente das pessoas que amam em estabelecer contatos físicos constantes com seus amados, pois esses contatos ampliam a sensação de bem-estar e prazer. Desse modo, tal manifestação está ligada ao interesse primitivo da pessoa e sua satisfação imediata; o outro se torna seu objeto de prazer. Isso provoca o aumento da tensão e do receio em perder o objeto de prazer, propiciando o surgimento de emoções conflitivas de medo, dor e raiva, características encontradas em muitos amantes.

Ao perderem uma relação de amor, as pessoas reagem, inicialmente, tornando-se frias, distantes e tristes, seus olhos ficam sem brilho, perdem a energia ativa de vida, a dor se torna visível, o corpo se retrai, os gestos se apresentam lentos, a expressão é triste, pesada e sem brilho, há, inicialmente, um fechamento para novos relacionamentos, surge uma desorganização interna, enfim, tendem a perceber a vida como sem graça, sentem-se desmotivadas. A pessoa tem a sensação de estar longe de seu centro, perdida e solitária, como se estivesse morrendo.

Outro aspecto importante para o estabelecimento de relações amorosas é o cognitivo, ligado à razão, pensamentos objetivos, troca de idéias, planos e projetos. Evidenciado na compreensão de Sócrates do surgimento do amor, esses itens precisam estar presentes, e é importante que sejam traçados juntos pelos amantes, pois possibilitam o aumento do desejo de permanecerem unidos, pois seria uma maneira de dar um pouco de segurança aos amantes que possuem sua porção de insegurança, herança mítica de Penia.

O mito de Eros, descrito de formas tão diversas, aponta sua complexidade, importância e dinâmica. A partir de nossa análise, podemos afirmar que a maneira de se expressar e sentir o amor se transforma ao longo da existência, pois esse é um processo interativo e evolutivo. Enfim, o amor é essencial para a realização e plenitude da pessoa, porque é o elemento que preenche de sentido a existência e humaniza as relações na medida em que abre espaço de existência para o outro junto a si. 
É importante, antes de encerrar, ressaltar que acreditamos que essa reflexão seja apenas uma pequena contribuição para ampliar a compreensão, o debate e o aprofundamento teórico sobre o sentido e os efeitos desse fenômeno tão complexo, importante e causador de tanto impacto sobre o nosso bem-estar e o da sociedade.

Acreditamos que não baste discutir o amor, é necessário criar condições para que ele se desenvolva e produza seus frutos: indivíduos plenos, felizes, confiantes, que assumam suas responsabilidades, e, conseqüentemente, possibilitem relações muito mais produtivas, construtivas e felizes.

\section{Referências}

Brandão, J.S. (1988). Mitologia Grega (4a ed., v.1-2, p.250). Rio de Janeiro: Vozes.

Bulfinch, T. (2000). O Livro de ouro da Mitologia: a idade da fábula; história de deuses e heróis (12a ed., p.101). Rio de Janeiro: Ediouro.
Cabral, A., \& Nick, E. (1974). Dicionário Técnico de Psicologia. São Paulo: Cultrix.

Dantas de Araujo, D.R. (2000). O amor no feminino: ocultamento ou revelação. Dissertação de Mestrado. Instituto de Psicologia; Universidade de São Paulo: São Paulo.

Durozoi, G., \& Roussel. A. (1993). Dicionário de Filosofia (3a ed.). Campinas: Papirus.

Hesíodo (1987). Teogonia: a origem dos deuses. São Paulo: Tecnoprint.

Houaiss, A. (2001). Dicionário Houaiss da língua portuguesa. Rio de Janeiro: Objetiva.

Fromm, E. (1971). A arte de amar. Belo Horizonte: Itatiaia.

Jung, C. (1978). O Homem e seus símbolos (3a ed.). Rio de Janeiro: Nova fronteira.

Platão. (2000). O Banquete (3a ed., pp.50-70). Mem Martins, Portugal: Europa-América.

Teilhard de Chardin, P. (1967). La energía humana. Madrid: Taurus.

Recebido para publicação em 17 de maio e aceito em 30 de novembro de 2004 
